\title{
GRAVITY ANOMALIES OVER THE GONGOLA ARM, UPPER BENUE TROUGH, NIGERIA.
}

\author{
E. M. SHEMANG, W. R. JACOBY and C. O. AJAYI \\ (Roceived 1 June 2004; Revision accepted 8 October, 2004)
}

\section{ABSTRACT}

A regional gravity survey of the Gongola Arm of the Benue trough was carried out with the aim of determining structures of interest. The results of the gravity interpretation showed that the area of study is characterised by negative Bouguer anomalies that trend in the NE-SW direction and range in value from -75 to $-15 \mathrm{mGal}$ with an average of $-42 \mathrm{mGal}$. A first order polynomial Was used to approximate the regional anomalies in the area. The residual gravity anomaly map shows anomalies that range in value from -32 to +20 mGal. $2.5-D$ modelling of the residual gravity anomalies suggests that the area has a horst and graben structure, with the grabens being as large as $60 \mathrm{~km}$ in width and filled with sediments that are up to $4.5 \mathrm{~km}$ thick. Results also suggest the existence of high-density rocks of basic composition at depth. The general indication of the structure of the Gongola arm of the Benue trough is that it is a half graben (width ca $60 \mathrm{~km}$ ) bounded by normal faults.

\section{INTRODUCTION}

The Gongola arm of the Upper Benue trough is part of the NE-SW trending $250 \mathrm{~km}$ wide and $1000 \mathrm{~km}$ long Benue rift structure (Fig. 1). The development of the Benue rift has been closely associated with the separation of Africa from. South America and the opening of South Atlantic Ocean.

The Benue rift can be compared with some well known rift systems such as the East African, the Rhine Graben, the Baikal rift and the Rio Grande rift. These rift systems are all associated with volcanism and regional uplift. Mareschal (1983) indicated the basic geophysical characteristics of a rift as having a thin crust, a low velocity and density upper mantle and higher than normal heat flow.

Geophysical studies in the Benue trough have shown that the crust trough is indeed thinned (Cratchley and Jones, 1965; Adighije, 1981; Ajayi and Ajakaiye, 1981; Osazuwa et al., 1981; Cracthley et al., 1984; Elf, 1985; Stuart et al., 1985; Saugy, 1987; Fairhead and Okereke 1987, 1990; Benkhelil et al., 1988). A low velocity and density upper mantle is inferred from gravity (Fairhead and Okereke 1987). There is also the presence of warm springs within the trough, thus suggesting enhanced heat flow.

There are also gross similarities between the Benue trough (depicter as a failed arm or aulocogen structure) and the East African Rift (Red Sea - Gulf of Aden - Afar triple junction). These similarities include the patterns of the gravity field of the Benue trough (a central high flanked onoth sides lows) and the central Red Sea, the contemporaneous magmatism and lead-zinc mineralisation, which are altributable to a triple junction.

The Gongola arm of the Benue rift system remains the part of the system that has not been completely covered bv previous gravity studies. The present study is a detailed gravity survey of the area carried out between 1993-1995 covering an area $49000 \mathrm{~km}^{2}$ between latitudes' $9^{\circ} 45^{\prime} \mathrm{N}$ and $11^{\circ} 00^{\prime} \mathrm{N}$ and longitudes $9^{\circ} 45^{\prime} \mathrm{E}$ and $13^{\circ} 00^{\prime} \mathrm{E}$. Gravity data were collected at $3 \mathrm{~km}$ intervals along all major and accessible roads in the area, resulting in 1150 gravity stations. Results of interpretation of the gravity field in the Gongola arm of the Benue trough is presented in this paper.

\section{Geological background}

The regional geological features of the Gongola area (Fig. 2) include a Precambrian crystalline basement made of granitoids and gneisses on which rest the Upper Cretaceous to Quaternary Sedimentary and Volcanic rocks (Carter et al., 1963; Benkhelil and Robinea4, 1983; Benkheli, 1988, 1989;
Maurin et al. 1985; Coulon et al, 1996). The Cretaceous sedimentary rocks include the continental Bima Sandstone; a major sandstone unit succeeded by transitional beds, which pass upwards into a Turonian to Senonian marine sequence. Continental conditions are believed to have been reestablished in the Maestrichtian that resulted in the deposition of the Gombe Sandstone (Maurin et al., 1985, Benkhelil. 1989). A period of folding then followed after which another continental sequence, the Tertiary Kerri-Kerri Formation was deposited. This formation unconformably overlies the continental Maestrichtian (Adegoke et al., 1986) along the western margin of the study area.

The Bima Sandstone occurs at the base of the sedimentary succession and is exposed in the cores of great anticlines and directly overlying the crystalline basement floor (Maurin et al., 1985). The thickness of the formation ranges from about $100 \mathrm{~m}$ to at least $3500 \mathrm{~m}$. The Yolde Formation, a sequence of sandstone and shale mark the transition from continental to marine sedimentation. This formation is diachronous and shows lateral variations in thickness, but is believed to be up to $380 \mathrm{~m}$ thick (Benkhelil, 1989). The Pindiga Formation is a sequence of marine shales, which include a number of limestone beds towards the base. At Gombe, boreholes have penetrated about $190 \mathrm{~m}$ of Pindiga Formation (Wardrop, 1989). The Gombe sandstone is a sequence of estuarine and deltaic sandstone, siltstones shales and ironstones. It is the top member of a folded and partly eroded sedimentary sequence and it is not possible to determine its original thickness. The Tertiary Kerri-Kerri Formation consists of a sequence of flatulying grits, sandstones and clays. This Palaeocene formation rests unconírmably upon folded Cretaceous rocks (Adegoke et al., 1986).

The Biu Plateau extends for over $1250 \mathrm{~km}^{2}$ of which the western margin (ca $250 \mathrm{~km}^{2}$ ) lies in the study area (Fig. 2). It is capped by Neogene sheets of olivine-basalts, prominent well-preserved volcanic vents with well-defined craters. The vents are composed of basaltic agglomerate, ash, lava, and tuffs. Small flows resting on the Plateau have been issued from these craters.

The structure of the Upper Benue Trough is much more complex than lower and middle parts of the trough and is characterised by cover tectonics (Benkhelil, 1988). The Upper Benue can be subdivided into several smaller units; the Kaltungo Inlier, formed by a horst of basement rock, the Pindiga.Gombe basin (Benkhelil, 1988), the Gombe ridge separating small deep basins and the Palaeocene flat-lying 


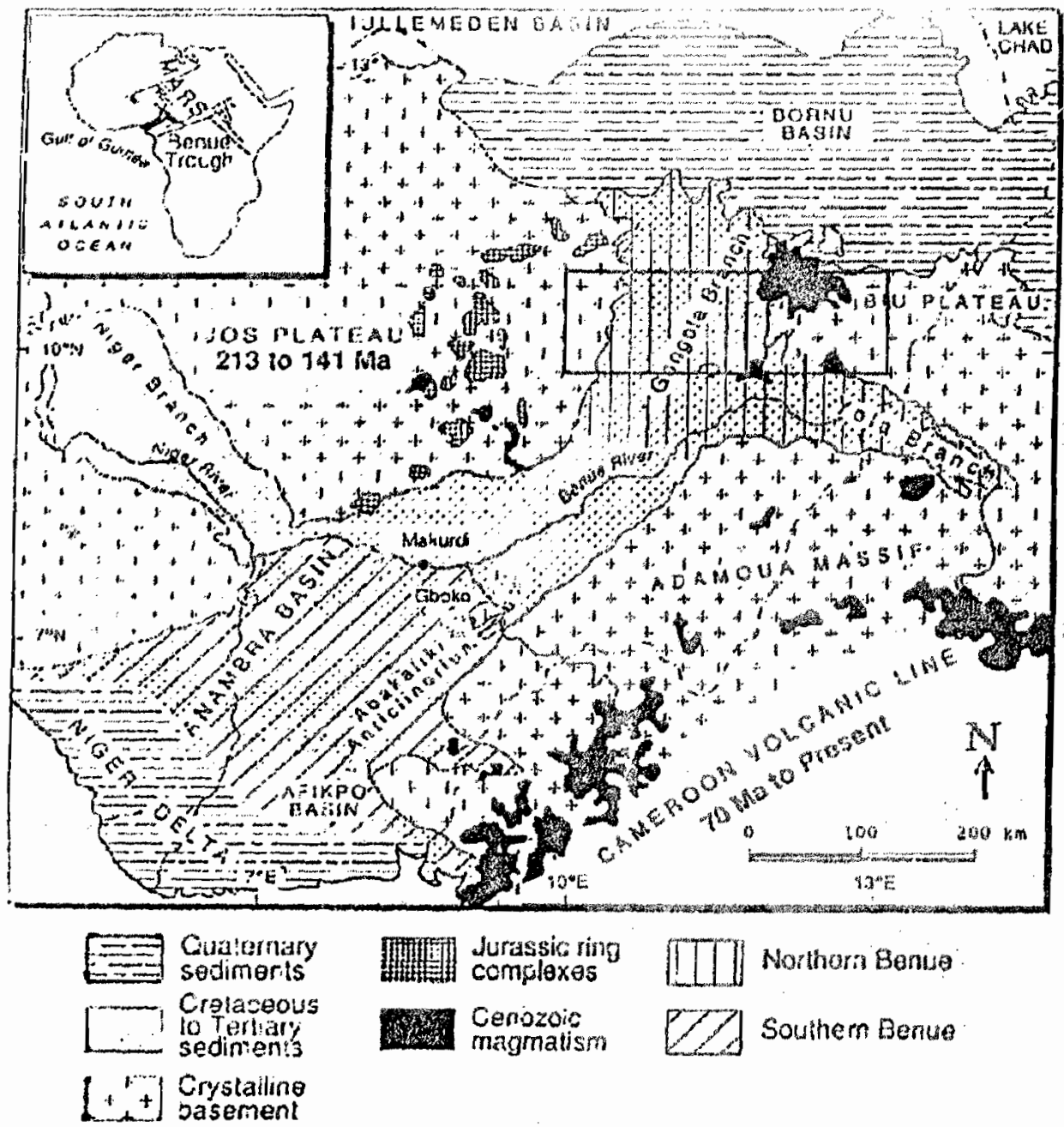

Fig 1 Location Map of the area of study (Adapted from Coulon of al, 1996). Solid rectangle indicates area of study.

Table 1: Density Values of rocks in the Gongola Arm of the Upper Benue Trough

$\begin{array}{lllllll}\text { Rock type } & \text { number of samples } & \text { range }\left(10^{-3} \mathrm{~kg} \mathrm{~m}^{-3}\right) & \text { dry } & \text { wet } & \text { mean } & \mathrm{S0} \\ \text { Biu basalt } & 10 & 2.58-2.78 & 2.77 & 2.79 & 2.78 & \pm 0.012 \\ \text { Kerri-Kerri Fm } & 15 & 2.30-2.5 & 2.38 & 2.39 & 2.40 & \pm 0.035 \\ \text { Gombe Fm } & 20 & 2.25-2.90 & 2.37 & 2.43 & 2.40 & \pm 0.100 \\ \text { Pindiga Fm } & 15 & 2.30-2.85 & 2.47 & 2.57 & 2.52 & \pm 0.025 \\ \text { Bima and Yolde Fm } & 40 & 2.40-2.80 & 2.46 & 2.48 & 2.47 & \pm 0.053 \\ \text { Older granite } & 20 & 2.40-2.76 & 2.59 & 2.60 & 2.82 & \pm 0.0112 \\ \text { Migmatite-Gneiss } & 30 & 2.65-2.77 & 2.69 & 2.70 & 2.70 & \pm 0.0710\end{array}$

Kerri-Kerri basin. The Gongola and Yola arms are digitations of the Upper Benue Trough and present a similar tectonic style.

Folding in the northeastern part of the Benue is PostMaestritchtian (Maurin et al., 1985; Benkheli, 1988). A notable display of this folding occurs in sediments of the area of study' where they are folded once gently and uniformly (Benkhelii, 1988). Tensional faulting is present in the sediments flanking the basement (Maurin et al., 1985) and within the crystalline rocks. The faults strike approximately at right angles to the basement boundary, and radially around the crystalline rocks. These faults probably represent adjustment to folding stresses (Adegoke et al., 1986).

\section{GRAVITY DATA COLLECTION AND REDUCTION.}

The gravity survey was carried out between 1993 and 1995 using a Lacoste-Romberg gravimeter. 1150 gravity stations were established at $3 \mathrm{~km}$ spacing on all available roads and tracks (Fig. 3) Two Wallace and Tieman altimeters were used to determine the station elevations. Base stations were established using the $A B A B C B C D$... 'looping' technique.

The heights obtained with the altimeters were tied to benchmark values and they agreed with the benchmark values within $1 \mathrm{~m}$.

Repeated obsenvation of gravity at data stations indicates an observational accuracy of $0.03 \mathrm{mGal}$. Errors in the Bouguer anomalies are not greater than $\pm 0.25 \mathrm{mGal}$, with the largest contribution coming from errors in staton elevations.

The regional base-network was tied to 3 bases earlier established by Osazuwa (1985) at Bauchi, Gombe and Biu. All reductions normally applied to raw gravity data were cantied out in order to obtain the Bouguer anomalies shown in Figure 3 The method of polynomial fitting (Zeng, 1989 and Beltrao et. al., 1991) was used to derive the regional anomaly using data uniformly sampled over the Bouguer anomalies. A tirs 


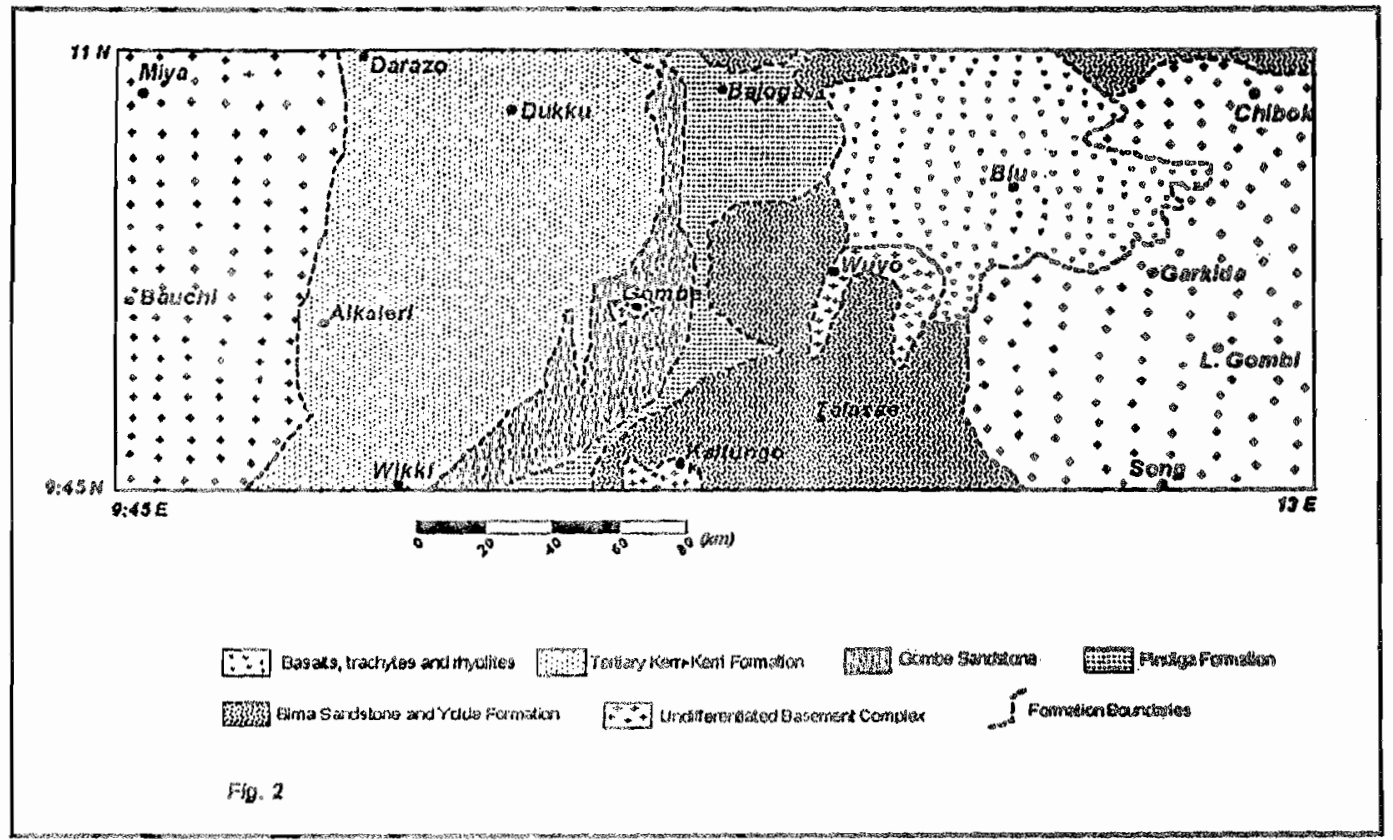

Fig.2 Geological Map of the Gongola Arm of the Upper Benue Trough, N.E Nigeria (after Geological Surveys of Nigeria 1994).

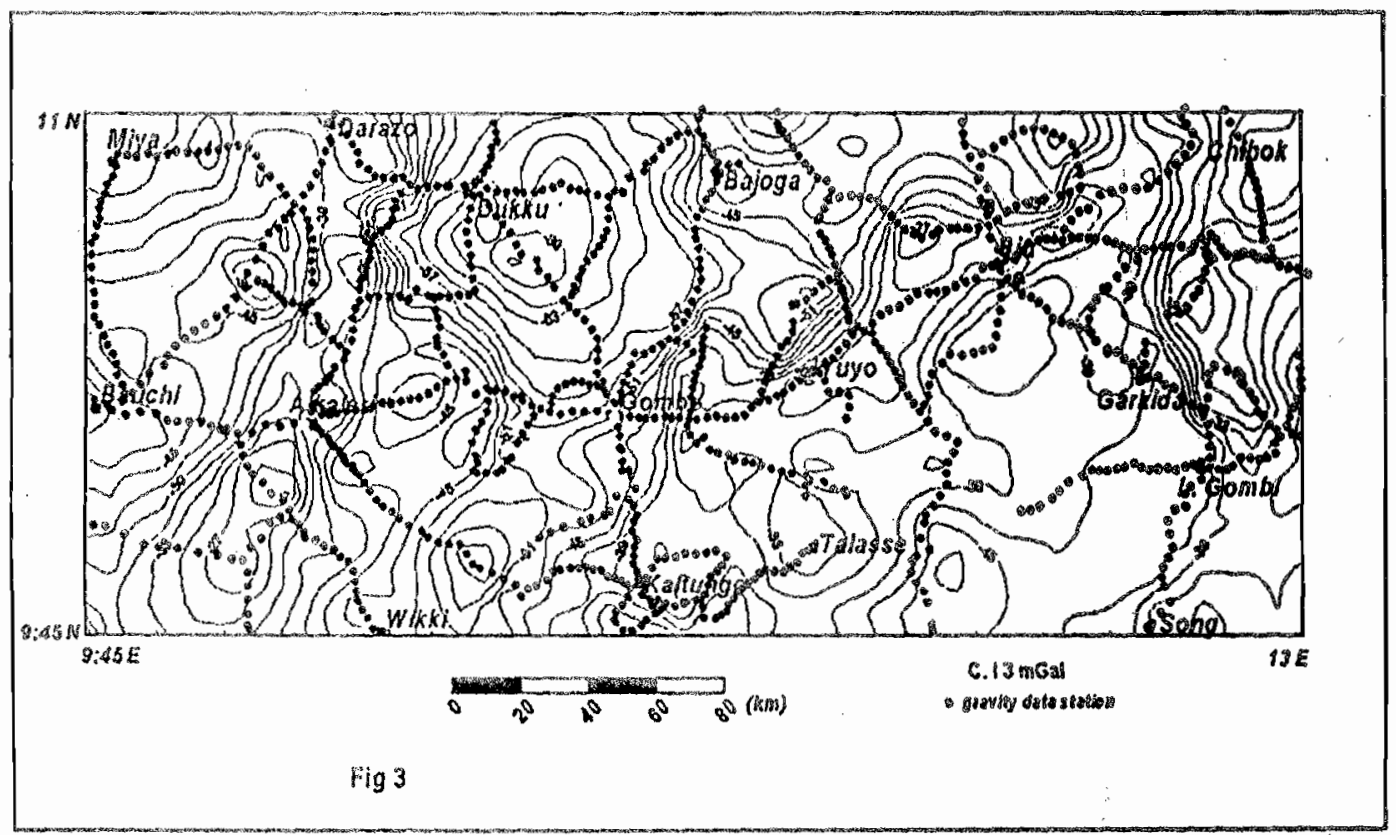

Fig.3 Bouguer Anomaly of The Gongola Arm of the Upper Benue Trough, Northeastern Nigeris

order surface was found to be an adequate representation of the regional anomaly. The residual anomalies superimposed on the geological map are shown in Fig. 4.

A lotal of 150 representative rock samples were collected for laboratory determination of densities. Table 1 summarizes representative rock densities collected during the sludy, while Table 2 gives the values obtained by previous workers (Cratchley and Jones, 1965: Ajayi, 1979 and Adighije, 1981) al a regional scale.

An inversion program package INVERT (Smilde, 1998) was used to interpret prominent anomalies in the study area

\section{INTERPRETATHONMETHOD}

Inversion of the gravity anomalies is used as a toof. A prion information is always needed. Quantitative interpretation and inversion, first of all, requires forward routines for computing gravity effects at observation points for assumed geometrical and density models. The program used has many options, but here only 2-d models are considered (at right angles to strike) and the fonward calculation of the gravity effects was done by the. Talwani et al. (1959) method. Limited background knowledge does not warrant the more complicated 3-d approach. The observation points are assumed at the topographic surface. The general inversion problem is nonlinear. The traditional "trial and epror" procedure is inadequale for exploring the model space.

The procedure is non-linear iterative inversion where the geometrical aspects of the modelling are stepwise linearized 
The 2: Generalised rock densities obtained in the BenueTrough

$\begin{array}{lcll}\text { Rock Type } & \text { Cratchley \& Jones, 1965; } & \text { Ajayi, 1979; } & \text { Adighije, 198 } \\ \text { Basement: } & 2.65 & 2.64 \pm 0.034 & 2.70 \pm .07 \\ \text { Shale (Albian) } & 2.65 & 2.65 \pm 0.04 & 2.62 \\ \text { Sandstone (Bima) } & 2.45-2.5 & 2.48 \pm 0.05 & - \\ \text { Sandstone (Turonian-Senonian) } 2.40-2.5 & 2.45 \pm 0.05 & 2.40 \pm 0.161 \\ \text { Shale (Turonian-Senonian) } & 2.50-2.55 & 2.53 \pm .02 & 2.60 \\ \text { Sandstone (Tertiary) } & 1.90-1.94 & 2.30 \pm 0.09 & \\ \text { Basic intrusions } & 2.75-3.00 & 2.64-2.90 & \end{array}$

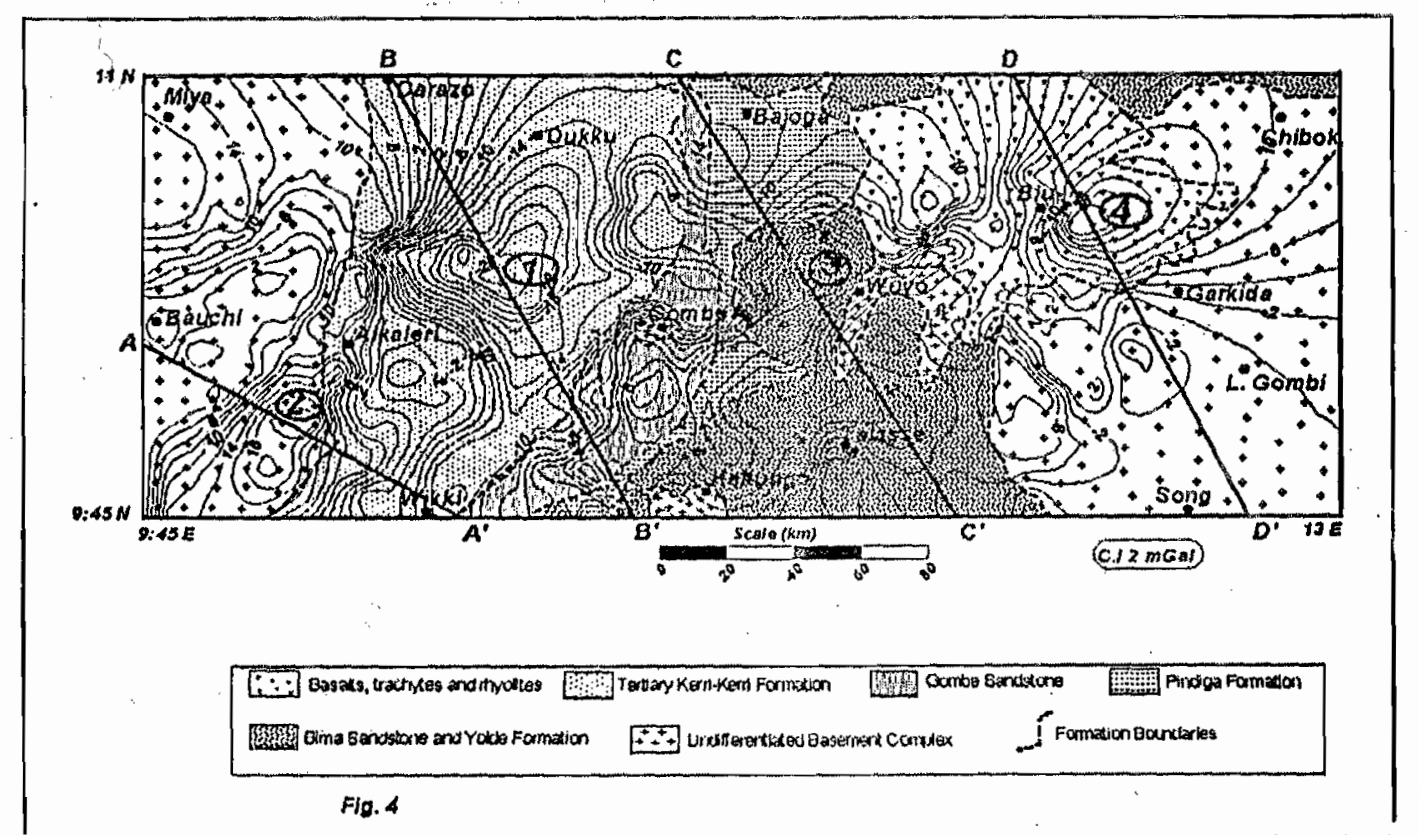

Fig.4 The Residual Bouguer anomaly map superimposed on the Geological map of the area of study. Indicated also are the locations of interpreted profiles A-D across anomalies 1-4
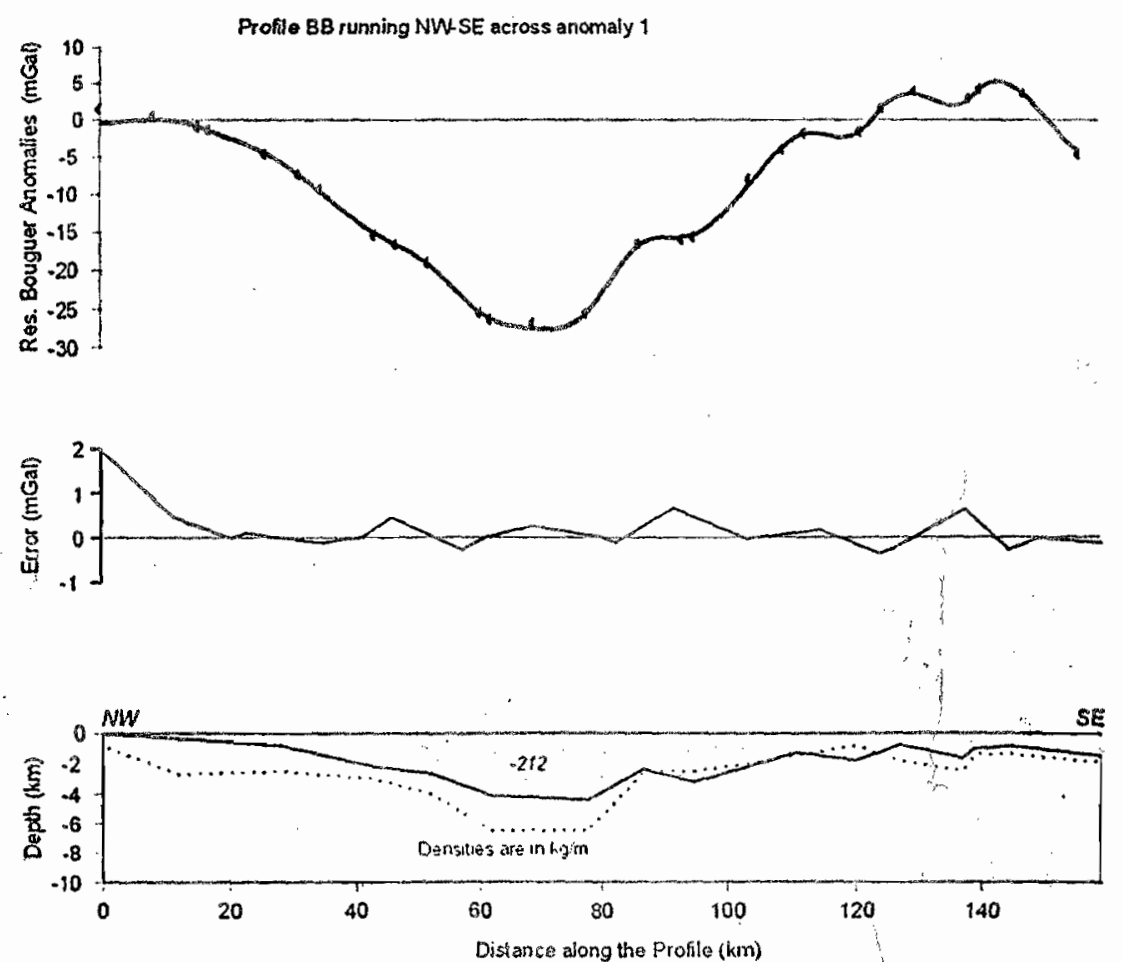

Fig.5 Simple 2.5D Interpretation of the Residual Bouguer anomalies along Profile BB'(fig. 4) in terms of a thick sedimentary cover. Density contrast between the basement and the sediments is $-212 \mathrm{~kg} / \mathrm{m}^{3}$ 
and the solution is obtained by iteration; the program package INVERT is used written by Smilde (1998). In a starting model both the a priori geometrical and density assumptions (parameters, e.g. coordinates) are specified and, equally important, the error limits of the parameters. In the Bayesian approach the model parameters and their uncertainties are treated equivalently to the data or observations. The a prion information comes from geophysical and geological data, sometimes simply guesses on the basis of comparison and experience. INVERT allows changing, and experimenting with, relative weighting of the gravity observations and the model parameters.

In INVERT the linearization is done by numerically: differentiating the field effects (at all observation poins) wim respect to all model parameters, i.e. by computing the eiiects At the initial values and closely neighbouring values of the pumeters. The linearized equations are the basis of the nomal equations to be solved for the parameter adjustments. Than new residuals are computed and new parameter edustments are computed the same way. The program allows is essume any norm, usualiy norm 2 (least-squares), but often - final terotion with norm 1, minimizing the sum of the absolute vilues of the residuals, will render the most stable results. By this procedure gravity and initial parameter values are fitted within their error limits for densities, depths and locations. Good judgement of the user is needed to decide
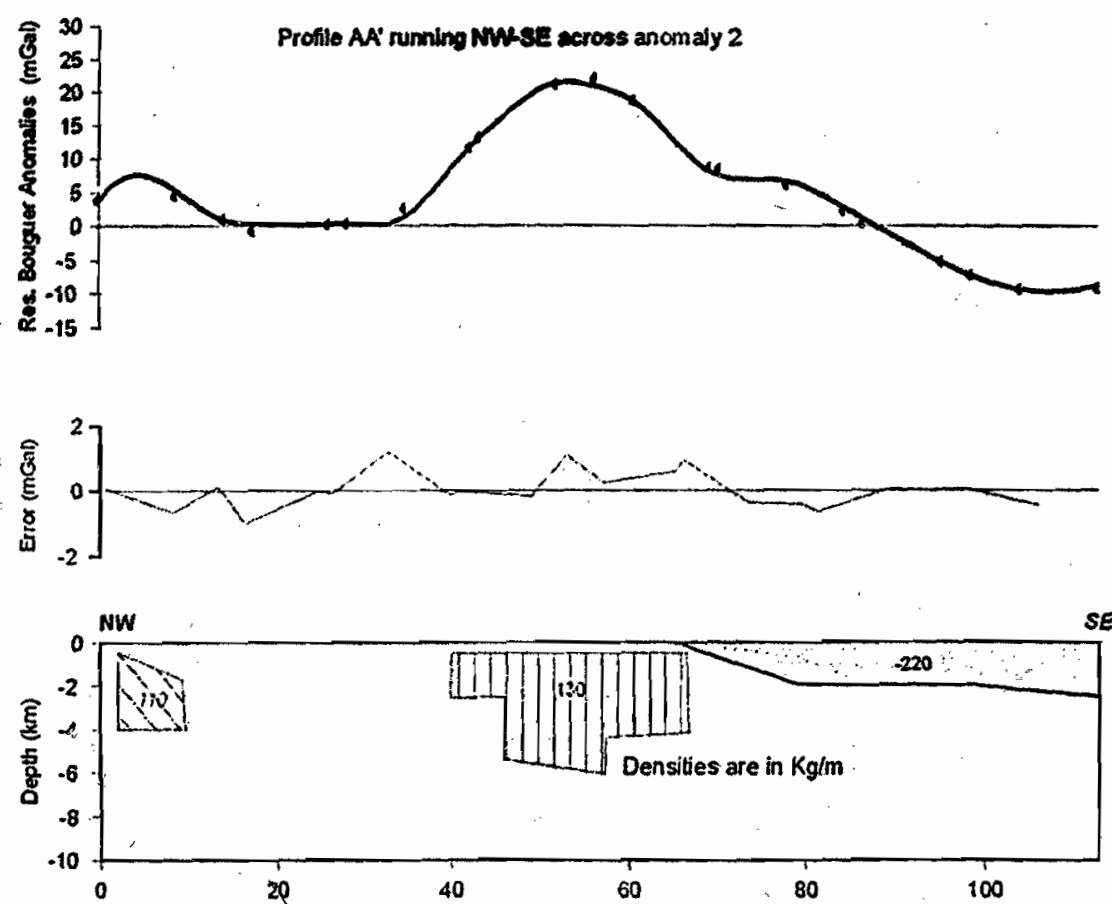

Fig.6 Simple 2.5D Interpretation of Residual Bouguer anomalies along profile $A A^{\prime}$ (fig. 4) in terms of: a marginal intrusion with a density contrast of $+130 \mathrm{~kg} / \mathrm{m}^{3}$. Density contrast between basement and the sediments is -220 $\mathrm{kg} / \mathrm{m}^{3}$. The presence of this intrusive at a depth of about $0.5 \mathrm{~km}$ was required for the anomalies to fit.
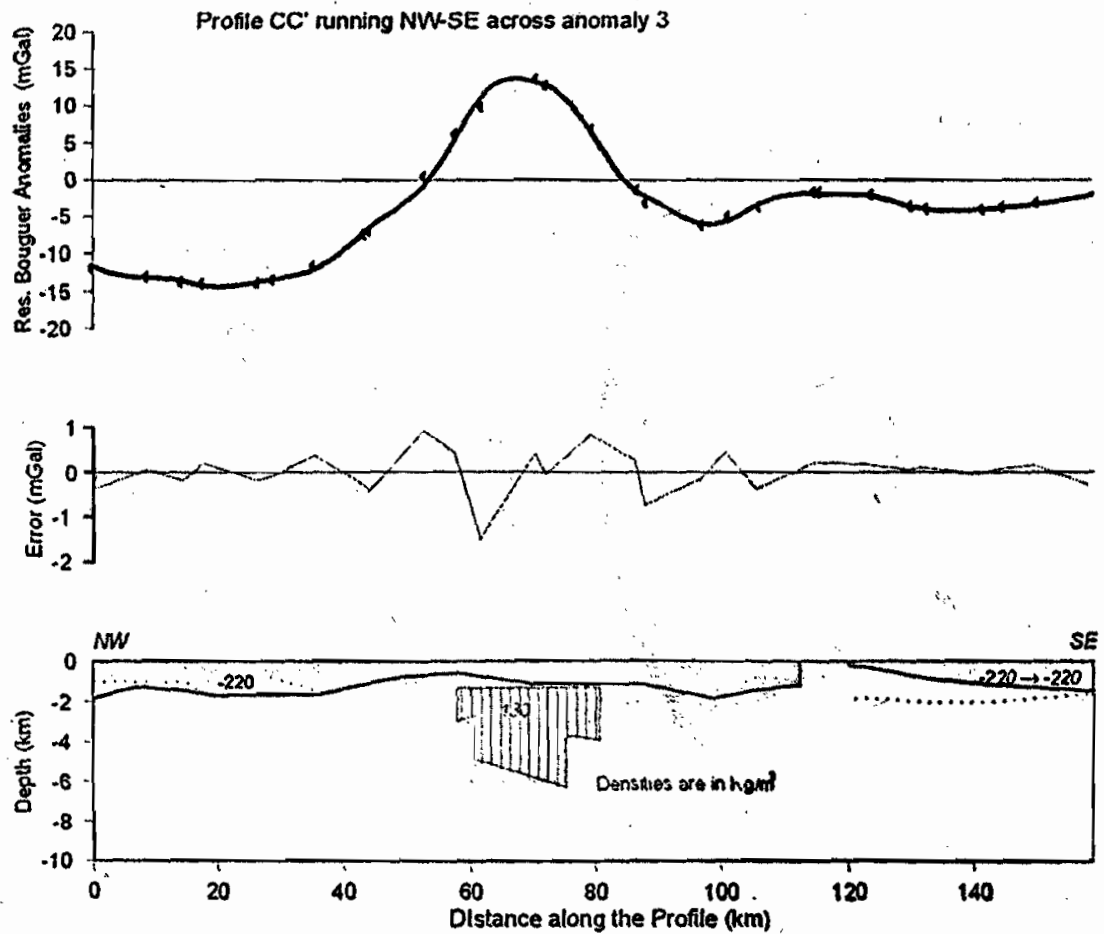

Fig.7 Simple 2.5D interpretation of Residual Bouguer anomalies along profile CC' (Fig. 4) in cover. Density contrast between the basement and the sediment is $-220 \mathrm{~kg} / \mathrm{m}^{3}$. Th intrusive at depth of density contrast of $+130 \mathrm{~kg} / \mathrm{m}^{3}$ was required for the anomalies to fit 
PROFILE DD' running NWSE across anomaly 4
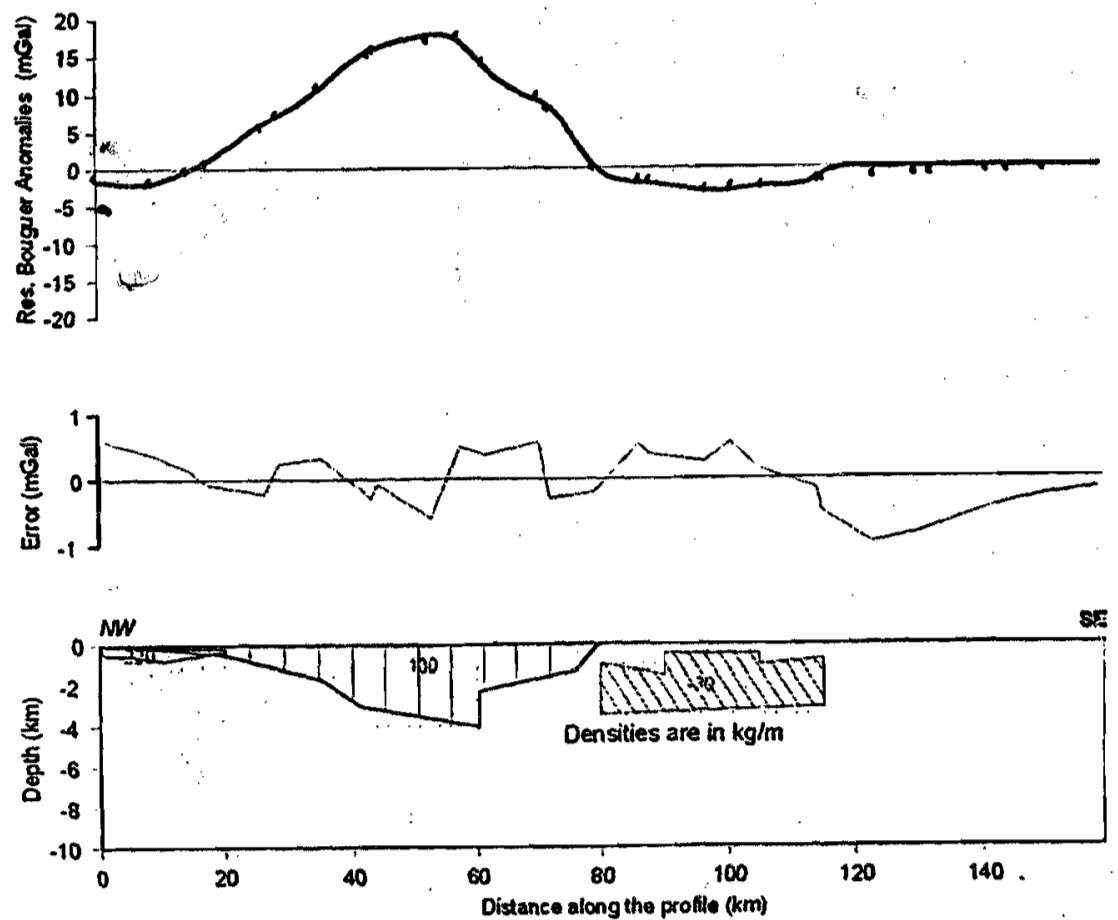

Fig.8 Simple 2.5D Interpretation of Residual Bouguer along profile DD' (Fig. 4). A dense body of density contrast $+130 \mathrm{~kg} / \mathrm{m}^{3}$ with the basement was required for the anomalies to fit. The presence of an intrusive granite body at depth with density contrast of $-30 \mathrm{~kg} / \mathrm{m}^{3}$ with the basement was inferred in the model.

whether a result is acceptable.

\section{RESULTS}

\section{Residual Anomalies and Surface Geology}

Figure 4 represents a superposition of the residual anomaly map on the geological map. This was used to carry out qualitative interpretations of the major anomalies in relation to the surface geology. Four profiles (1-4) across major anomalies were selected for two-dimensional modeling and interpretation and the results are used to support the qualitative interpretation. The anomalies are due to density contrasts between the rift sedimentary rocks (Cretaceous and Tertiary) and the underlying basement or intrabasinal mafic intrusions.

\section{Anomaly 1}

This anomaly is characterised by negative Bouguer values of up to $-75 \mathrm{mGal}$ (Fig. 3). The anomaly is centred between Alkaleri, Dukku and Gombe (Fig. 4), entirely located over the Neogene and Cretaceous sedimentary rocks.

Figure 5 is the result of 2-D modelling along profile BB'. The profile runs NW-SE over the sedimentary sequence and covers a distance of about $160 \mathrm{~km}$ (Fig. 4). The observed and computed anomalies together with the vertical cross-section for the interpreted model of the profile are shown in Figure 5. A density of $2670 \mathrm{~kg} \mathrm{~m}-3$, which is the average value determined for the basement rocks (Table 1), was used for the modelling, while a statistically determined average of $2450 \mathrm{~kg}$ $\mathrm{m}-3$ was used for the sediments. The model suggests that the Cretaceous sediments attain a maximum thickness of $4.5 \mathrm{~km}$ towards the centre of the profile (Fig. 5). The computed anomalies are seen to fit the observed anomalies within \pm 2 mGal (Fig. 5). The deduction that could be made from the model is that block faulting led to the development of a graben filled by sediments.

\section{Anomaly 2}

The gravity anomaly 2 is a positive gravity anomaly lying SE of Bauchi and SW of Alkaleri (Fig. 4). This anomaly trends in a NE-SW direction, about $100 \mathrm{~km}$ long and $25 \mathrm{~km}$ wide. It stretches from beyond Alkaleri to the southwestern end of the map at the western margin of the basin. Here the Tertiary Kerri-Kerri Formation is in contact with outcrops of the basement complex and the thickness of the sediments is believed to be very small ( $>2 \mathrm{~km}$ ). This anomaly coincides with the axial positive anomaly of Fairhead and Okereke (1987). Previously, these authors were unable to properly identify this positive anomaly because of lack of data. The anomaly suggests the existence of high-density igneous mafic rocks at depth. along the margin of the trough. Suh et al. (2000) identified highly tectonised zones along the basement sediment contact intruded by mafic rocks. Volcanic rocks at Bashar in the middle Benue trough and Biu in the east (Fig. 2) could be the volcanic expression of the igneous bodies.

The 2.5 dimensional modelling along profile $A A^{\prime}$ (Fig. 6) that cuts across anomaly 2 suggests the existence of a about $25 \mathrm{~km}$ wide high density body $\left(2800 \mathrm{~kg} \mathrm{~m}^{-3}\right)$ with a width of about $25 \mathrm{~km}$ at a depth of ca $0.5 \mathrm{~km}$ beneath the surface. The modelling suggests a ca $2 \mathrm{~km}$ thick sediments infill in the eastern margin of the profile.

\section{Anomaly 3}

Anomaly 3 (Fig. 4) is positive gravity anomaly of up to $14 \mathrm{mGal}$ and is possibly due to very shallow basement rocks and a thin sedimentary cover. Alternatively this could mark mafic intrusions below and/or within the sediments. The 2-D modelling along the NW-SE trending profile CC' (Fig. 7), suggest that the positive anomaly on this profile is due to the existence of mafic intrusives. A density of about $2800 \mathrm{~kg} \mathrm{~m}^{-3}$ was assumed for the intrusive. The model (Fig. 7) reveals that the bodies occur between 1 and $6 \mathrm{~km}$. The Cretaceous sediments of density $2450 \mathrm{~kg} \mathrm{~m}^{-3}$ along this profile have a maximum thickness of ca $1.8 \mathrm{~km}$. 


\section{Anomaly 4}

Anomaly 4 occurs around Biu and is a positive anomaly with a maximum value of $+18 \mathrm{mGals}$ (Fig. 4). It is caused by mafic intrusive bodies inferred to be the roots of the Biu basalts. Figure 8 is the 2.5 dimensional modelling for profile DD' which extends for a distance of about $160 \mathrm{~km}$. The source of the large positive anomaly is modelled using a ca 20 $\mathrm{km}$ wide mafic body, which spreads out, at a distance of about $80 \mathrm{~km}$. An older granite suite (of density $2637 \mathrm{~kg} \mathrm{~m}^{-3}$ ) was modelled to be part of the basement rocks at depths between 0.5 and $3 \mathrm{~km}$ along the profile. This probably accounts for the low gravily between 100 and $118 \mathrm{~km}$ along the profile. The model suggests that the basaltic flow at the north-western end of the profile is a thin layer overlying the Cretaceous sediments that are up to $0.9 \mathrm{~km}$ thick.

\section{Crustal Structure of the area}

The crust and upper mantle under the Gongola arm of the Upper Benue Trough and adjacent areas were modelled along profile QQ' using the gravity field over the area.

Figure 9a shows a plot of the Bouguer anomalies along profile $\mathrm{QQ}$. The observed Bouguer anomalies along this profile were resolved by matching marginal gradients and extending them smoothly, as carried out by Ajayi (1987) for the gravity data within the Benue Trough, into the foliowing three components :

1. a very long wavelength $(\lambda=350, \mathrm{~km})$ negative anomaly, and assumed to be due to asthenospheric rise under the trough (Fig 9a).

2. an intermediate $(\lambda=250 \mathrm{~km})$ positive anomaly, also centred over the trough which is considered to be due to crustal thinning (Moho uplift) under the area of study (Fig. $9 b)$ and
3. a short wavelength $(\lambda=180 \mathrm{~km})$ negative anomaly due to the Cretaceous and Tertiary sediments filling the trough.

Figure 9c is a plot of the topography along this profile (QQ'). The topography along this profile is plotted in order to be able to determine whether or not the area is isostatically compensated.

Figures $9 a$ and $c$ shows that aninverse relationship exist between the Bouguer anomalies and topography in the area of study suggesting that the area is isostatically compensated.

Two-dimensional modelling was carried out for Profile $Q Q$ ' to determine the crustal structure in the area. An average crustal thickness of $34 \mathrm{~km}$ was obtained in the project area and this value corresponds to that obtained by Fairhead and Okereke (1987) for the Yola arm of the Benue trough just to the south-east of the present project area.

Figure 10 shows the interpreted gravity model for Profile $Q^{\prime}$. A density contrast of $+0.17 \mathrm{~g} \mathrm{~cm}^{-3}$ between the base of the crust and upper mantle was used. The model for the dense mantle body has outward sloping flanks which are steeper on the western margin than the eastern one. This assymetry probably reflects, to some extent, the nature of the upper mantle beneath the Biu Plateau (Fig. 2) to the northeast. The width of the uplifted Moho (crustal thinning) is about $50 \mathrm{~km}$ giving a Moho rise of $5.5 \mathrm{~km}$ from $34 \mathrm{~km}$. It is evident from Figure 10 that the Moho uplift broadens at the base extending over about $200 \mathrm{~km}$.

\section{DISCUSSION AND CONCLUSIONS}

Gravity anomalies have been used to investigate the framework of the Gongola Arm of the Benue rift system.

The results of the interpretations of gravity anomalies
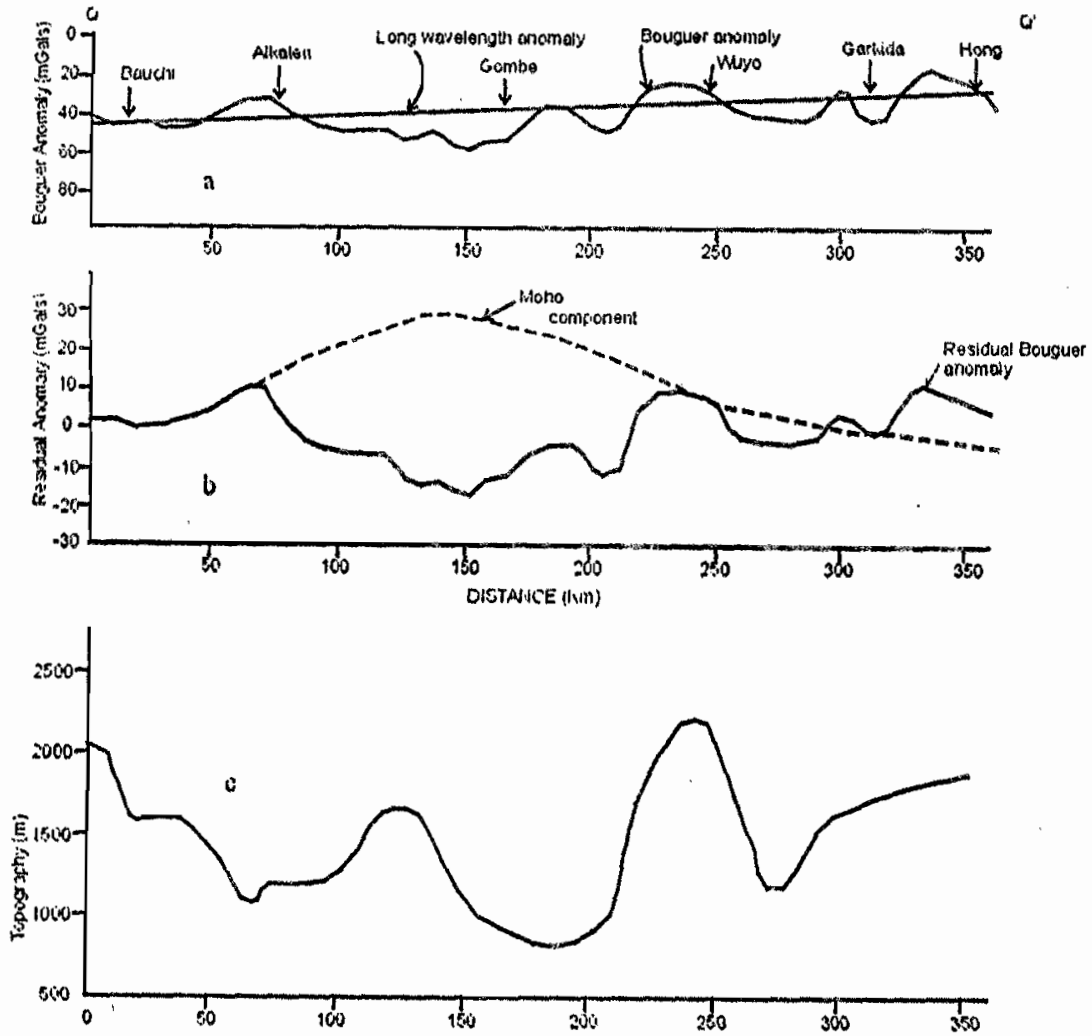

Fig. 9 Plot of Bouguer Gravity and Topography along profile QQ' across the Gongola Arm of the Benue Trough 

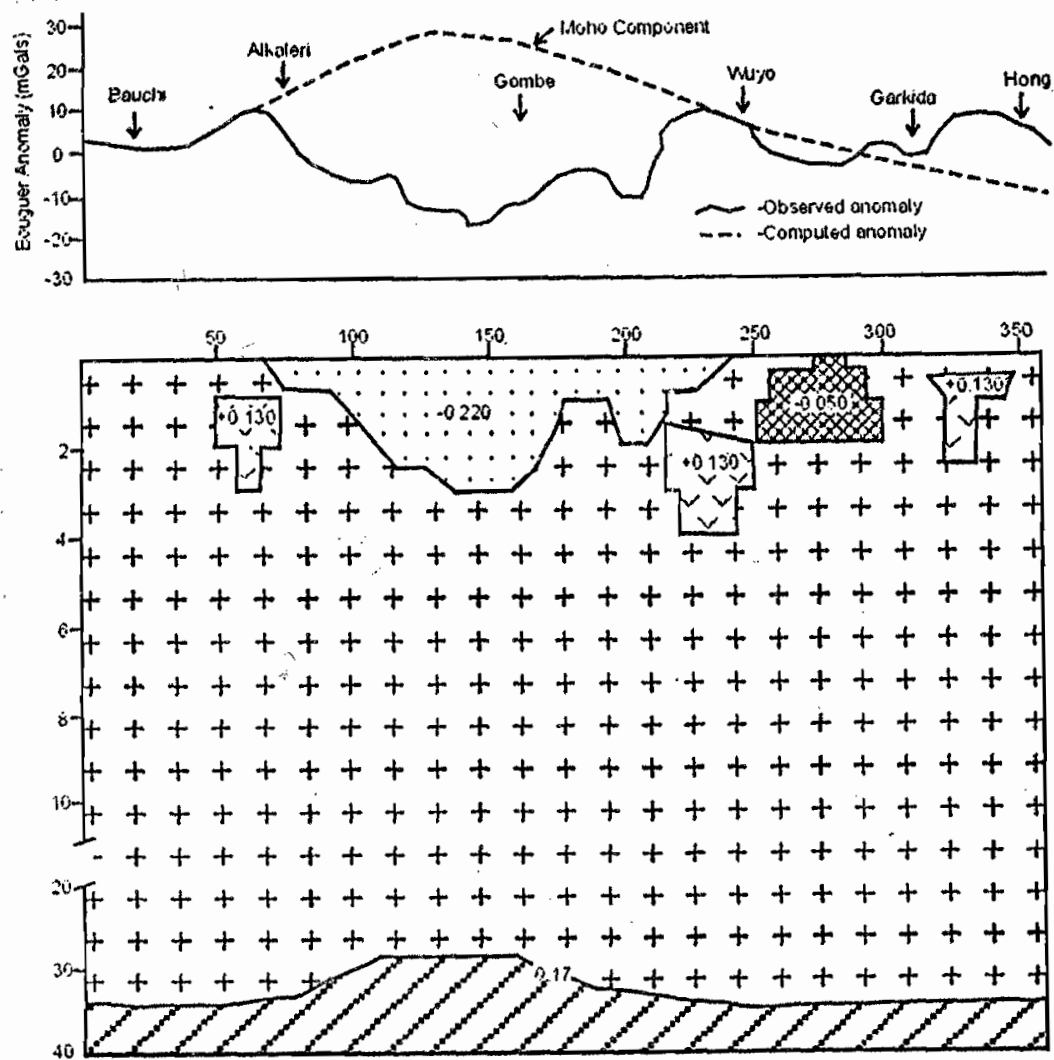

Fig. 10 Simple 2-D Crustal Model of the Area of Study along profile QQ'

$\square$ Sediments $\square$ Older granite $\square$ Basic intrusives $\square$ Upper mantle

suggest the existence of intra basement intrusives of high densities in the trough at depths between about 0.5 and $2 \mathrm{~km}$. The existence of intrusive in suggests the existence of deeply penetrating fractures within the area. Basic intrusives have been inferred from results of geophysical studies conducted in different parts of the world over major rift systems such as the Rhine Graben and the Baikal rift (Zorin et al., 1975; Zorin, 1971, 1981, Logatchev, 1993).

The prominent negative residual anomaly 1 between Dukku, Gombe and Alkaleri (Figs. 4\& 5) shows a graben filled with sediments has been interpreted as a basement depression, which has been filled with sediments. This graben is hereby called the Dukku sub-basin or Dukku Graben. The results of the interpretation suggest that the graben is filled with sediments of thickness about $4.5 \mathrm{~km}$ and is about $60 \mathrm{~km}$ wide. For the sediments to have attained a thickness of about $4.5 \mathrm{~km}$, within such a short distance from the basement, suggests that block faulting most likely took place in the area. The existence of block faulting has been suggested in the area Adegoke et al. (1986), and Enu (pers. communication, 1995).

Field evidence also suggests that block faulting took place in the area. This evidence includes the sheared and fractured Kaltungo inlier (Maurin et. al., 1985), the highly sheared/fractured basement outcrop (inlier) around Gombe, and the sheared/fractured basement outcrop around Wuyo (Fig. 2) also in the area of study. These inliers could have been brought up to the surface by fault movements; and they are most likely to be the upthrown blocks of the fault movements, while the down-thrown blocks must have formed grabens such as the one seen in this area.

The results of the study in the area suggest that the area of study is essentially made up of graben and horst structure, with associated basic intrusion at depth. The width of ca $60 \mathrm{~km}$ is similar to more mature contiriental rifts such the Baikal rift, and thus suggesting that the width of these rift was acquired early in the evolution of of the rift. The differential block faulting observed in the area is believed to be a resuit of mantle upwelling and regional tension that were concentrated near deep crustal faults, and emplacement of basic intrusions in close association to these faults. Buried basic intrusives exist at depths ranging from $0.5-2 \mathrm{~km}$, suggesting the existence of deep fissures in the crust beneath the area of study, which might have originated during rifting and parts of which became the foci of intrusives into the crust.

\section{ACKNOWLEDGEMENTS}

The authors will like to thank Dr Herbert Wallner of the Geophysics Group of the Mainz Universitat; the DAAD Academic Exchange programme for financing the stay of the first author at the Universitaet of Mainz, which enabled the successful completion of this work and the Abubakar Tafawa Balewa University Bauchi. Nigeria authorities are gratefully acknowledged for providing funds for the fieldwork.

\section{REFERENCES}

Adegoke, O. S., Jan du Chene, R. E., Agumanu, A. E. and Ajayi, P. O., 1986. New stratigraphic, sedimentologic and structural data on the Kerri-Kerri Formation, Bauchi and Borno States, Nigeria. Journal African Earth Sciences 5: 249-277.

Adighije, C. I., 1981. A Gravity Study of the Lower Benue Trough, Nigeria, Geological Magazine 118: 59-67. 
Ajayi, C. O., 1979. A detailed Gravity survey of the Middle Benue. Ph.D. thesis, Ahmadu Bello University, Zaria Nigeria.

Ajayi C. O., 1987. A preliminary lithospheric (crust and upper mantle) interpretation of the gravity data from the Benue trough and adjacent areas. In: Matheis and Schandeimeier (Eds.), Current researches in African earth sciences, Balkema, Rotterdam, 293-294.

Ajayi, C. O. and Ajakaiye, D. E., 1981. The origin and peculiarities of the Benue Trough: another look from recent gravity data in the Middle Benue. Tectonophysics 80: 285-303.

Beltrao, J.F., Silva, J.B.C and Costa J.C., 1991. Robust polynomial fitting method for regional gravity estimation. Geophysics 56: 80-89

Benkhelil, J., 1988. Structure end geodynamic evolution of the intracratonic Benue Trough (Nig.). Bulletin Centres Recherge Exploration and Production Elf-Aquintane $12: 29-128$

Benkhelil, J., 1989. The origin and evolution of the Cretaceous Benue Trough Nigeria. Journal African Earth Sciences. 6. 251-282.

Benkhelil, J. and Robineau, B., 1983. Is the Benue Trough a Rift? Bulletin Centres Recherche Exploration Production, Elf-Aquitane. 7: 315-321.

Benkhelil, J., Dainelli, P., Ponsard, J.F., Popoff, M. and Saugy, L., 1988. The Benue Trough: Wrench fault related basin, on the border of the Equatorial Atlantic. In: (Manspeizer, W. Ed.), Triassic-Jurassic Rifting, Continental Breakup and the origin of the Atlantic Ocean and passive Margins. (Developments in Geotectonics, 22). Elsevier Amsterdam, 789-819.

Carter, J.D. Barber, W., and Tait, E.A., 1963. Geology of Adamawa Bauchi and Bornu Provinces in northeastern Nigeria. Bulletin Geological Survey Nigeria 32: 1-108.

Coulun, C., Vidal, $P$., Dupuy, C., Popoff, M., Maluski, H. and Hermite D., 1996. The Mesozoic to early Cenozoic magmatism of the Benue Trough (Nigeria); Geochemical evidence for the involvement of the St Helena Plume. Journal Petrology, 37: 1341-1358.

Cratchley, C.R. and Jones, J. P., 1965. An interpretation of the geology and gravity anomalies of the Benue valley, Nigeria. Overseas geological Survey Geophysical paper 9: 1-28.

Cratchley, C.R., Louis, P. and Ajakaiye, D.E., 1984. Geophysical and Geological Evidence for the BenueChad Basin Cretaceous Rift valley Systems and its Tectonic Implications. Journal African Earth Sciences 2: $141-150$.

Elf Nig. Lid., 1985. Structural Interpretation of the Benue Trough and the Bornu Basin. Unpublished report, Lagos 59 pp.

Fairhead, J.D. and Okereke, C. S., 1987. A regional gravity study of the West African Rift System in Nigeria and Cameroon and its tectonic interpretation; Tectonophysics 143:141-159.

Fairhead, J.D. and Okereke, C.S., 1990. Crustal thinning and extension beneath Benue trough based on gravity studies. Journal African Earth Sciences 11: 329-335.
Logatchev, N. A., 1993. History and geodynamics of Baikal rift (east Siberia): A review: Bulletin du centre de la Recherche Exploration Production Ef Aquitanne 17: 353-370

Mareschal, J., 1983. Mechanisms of Uplift Preceeding Rifting. Tectonophysics 94: 51-66.

Maurin, J.C., Benkhelil, J. and Robineau, B., 1985. Fault rocks of the Kaltungo lineament, NE Nigeria and their relationship with the Benue trough tectonics. Journal Geological Society London 143: 587-599.

Osazuwa, I. B., 1985. The establishment of a primary gravity network for Nigeria. Ph.D. thesis, Ahmadu Bello University, Zaria, Nigeria.

Osazuwa, I.B., Ajakaiye, D.E. and Verheijen P.J.T., 1981. Analysis of the structure of Part of the Upper Benue Rift Valley on the Basis of new Geophysical data. Earth Evolutionary Sciences 2: 126-135.

Saugy, L., 1987. The Benue Trough and Bornu Basin: New geophysical data.enlightenning the distribution of Cretacoeus Sedimentary basins. Bulletin Centres Recherche Exploration Production Elf-Aquitane. 11: 178-180.

Smilde, P.L., 1998. Venwendung und Bewertung von a priori Information beio potentiell singulären Inversionsproblemen am Beispiel der gravimetrischen Bestimmung von Dichteverteilungen. DGK, Reihe C, Heft Nr. 490, München.

Suh, C.E., Shemang, E.M., Dada, S.S., Samaila, N.K., and Likkason O.K., 2000. Brittle events at the South-Eastern Margin of the Kerri-kerri Basin (N.E. Nigeria): Evidence for a Post-Palaeocene extensional regime in the Upper Benue Trough. NAPE Bulletin 15: 1-15.

Stuart, G.W., Fairhead, J.D., Dorbath, L. and Dorbath, C. 1985. A Seismic Refraction study of the Crustal Structure Associated with the Adamawa Plateau and Garoua Rift; West Africa. Geophys. Joumal Royal Astronomical Society 81, 1-12.

Talwani, M., Worzel, J. L. and Landisman, M. 1959. Rapid gravity computations for two-dimensional bodies with application to the Mendocino submarine fracture zone. J. Geophys. Res., 64: 49-59.

Wardrop Engineering Inc., 1989. Hydrogeology and Borehole data Phase II Rural Borehole Project report, Volume 2. 350pp. Bauchi State Agricultural Development Programme Development/Bauchi, State (Nigeria) Integrated Rural development Authority.

Zeng, H., 1989. Estimation of the degree of polynomialfitted to gravity anomalies and its application. Geophysical Prospecting 37: $959-973$.

Zorin, Yu. A., 1971. Recent structure and isostacy of the Baikal Rift Zone and adjacent areas. Nauka Moscow.

Zorin Yu. A., 1981. The Baikal rift: an example of the intrusion of asthenospheric material into the lithosphere as the cause of disruption of lithospheric plates. Tectonophysics 73: 91-104.

Zorin Yu., A., Lysake, S.V. and Golubev, V.A., 1975. On the nature of the geothermal anomaly in Baikal area In :Baikatsky Rift, pp 66-73, Nauka Moscow. 